\section{Bienvenida a la reedición de Educación Médica}

\author{
Arcadi Gual, Maria Nolla-Domenjó, Jordi Palés-Argullós
}

\section{Welcome to the republication of Educación Médica}

La editorial Elsevier acaba de recuperar una publicación que en su día arrinconó: Educación Médica. Es, sin duda, una magnífica noticia y desde la Fundación Educación Médica (FEM) no podemos dejar de aplaudir a los promotores de este rescate y congratularnos por este logro. iAlbricias, albricias, y pan de Madagascar!

Pero, ¿dónde ha estado Educación Médica todos estos años? Hagamos un poco de historia. En 1998, Ediciones Doyma, con el apoyo incondicional de su director, José A. Dotú, alumbraba la revista Educación Médica bajo la dirección de nuestra fundación, la FEM. Fueron unos inicios cargados de esfuerzo e ilusión por crear un órgano de expresión abierto a todos los interesados en la educación médica de habla hispana. Después de cinco años de publicación ininterrumpida y exitosa de la revista, Ediciones Doyma, tras diferentes vicisitudes, pasó a manos de Elsevier. Ese mismo año, los nuevos propietarios, al parecer no muy interesados en nuestro ámbito de conocimiento, cedieron la cabecera de la publicación a la FEM, que siguió adelante con el proyecto con renovados ánimos e idéntico entusiasmo. De la mano de Viguera Editores, la FEM continuó la publicación de Educación Médica durante toda una década, hasta que en el año 2012 Elsevier quiso recobrar la cesión temporal de la que disfrutaba la FEM. A partir de ese momento, la FEM y su equipo continuaron el trabajo editorial bajo una nueva cabecera, FEM-Revista de la Fundación Educación Médica. De este modo, con mucho esfuerzo y dedicación altruista, y sorteando no pocas dificultades, la fundación ha dirigido durante más de 18 años consecutivos no sólo la revista mencionada, sino que ha generado diferentes publicaciones del área de la educación médica y ha desplegado una intensa actividad en este campo.

Desde su constitución hace casi 20 años, la FEM, una entidad sin ánimo de lucro, ha estado plena-
The publishing company Elsevier has just retrieved a publication that it discarded some time ago: Educación Médica. This is undoubtedly marvellous news and here at the Fundación Educación Médica (FEM) we can but put our hands together and applaud the promoters behind the salvaging of this journal and congratulate ourselves on what we have achieved. Hurray! Hurray!

But where has Educación Médica been all these years? Let's go back in time a little. In 1998, Ediciones Doyma, with the unconditional support of its director, José A. Dotú, brought the journal Educación Médica into being under the direction of our foundation, the FEM. Those early days were brimming with effort and enthusiasm to create a mouthpiece that was open to all those interested in medical education in the Spanish-speaking world. After five years of successful non-stop publication of the journal, Ediciones Doyma, faced with a growing number of different adversities, was taken over by Elsevier. That same year, the new owners, who did not seem very interested in our field of knowledge, handed the masthead of the publication over to the FEM, which continued with the project with renewed spirits and the same enthusiasm. Thanks to the support of Viguera Editores, the FEM continued to publish Educación Médica for a whole decade, up until the year 2012, when Elsevier reclaimed the temporary transfer the FEM had been enjoying up until then. From then on, the FEM and its team continued to publish under a new name, FEMRevista de la Fundación Educación Médica. Thus, with a great deal of effort and altruistic dedication, and overcoming more than its fair share of difficulties, the Foundation has directed for over 18 years on the run not only the above-mentioned journal but also several other publications in the field of medical education and has been very active in this area.
Fundación Educación Médica (FEM).

Coordinación/Correspondencia: Fundación Educación Médica. Departamento de Ciencias Fisiológicas I. Facultad de Medicina. Universitat de Barcelona. Casanova, 143. E-08036 Barcelona.

E-mail:

agual@

fundacioneducacionmedica.cat (c) 2015 FEM 
mente convencida de la necesidad de difundir y prestigiar el nuevo ámbito de conocimiento que representa la educación médica. Por ello, la fundación ha trabajado denodadamente para mantener, viva y activa, una publicación de la máxima calidad científica. No cabe duda de que este esfuerzo generoso de la FEM tiene nombres y apellidos concretos, pero también es preciso reconocer, como partes imprescindibles en este logro, el respaldo y los auspicios de diversas instituciones nacionales e internacionales implicadas en la educación médica, como la Association for Medical Education in Europe (AMEE), la World Federation for Medical Education (WFME), y la Federación Panamericana de Asociaciones de Facultades y Escuelas de Medicina (FEPAFEM-PAFAMS), la Conferencia Nacional de Decanos de Facultades de Medicina (CNDMED) y la Sociedad Española de Educación Médica (SEDEM), quienes desde el primer momento apoyaron institucionalmente a la fundación en su tarea. No menos importante ha sido el sostén de un equipo editorial inmejorable con el que ha contado la dirección de la revista, y que merece aquí su justo reconocimiento público.

Pero lo que ahora nos ocupa no es este trabajo filantrópico de casi dos décadas en pro de la educación médica realizado por la FEM, sino la recuperación de la revista Educación Médica. Efectivamente, Elsevier, tras tres años de completo abandono, ha encargado la dirección de la revista a un equipo solvente y experimentado, como es el que representan los Dres. Millán Núñez-Cortés, Gutiérrez Fuentes y Morán Barrios. Ellos, con el patrocinio de la Fundación Lilly, se harán cargo de resucitar la publicación. La dilatada trayectoria de los nuevos responsables de la revista en el campo de la educación médica y el decidido respaldo de instituciones tan prósperas como la Cátedra EducaciónFundación Lilly son garantía de éxito para esta nueva época de la revista. El primer número de esta segunda etapa ha aparecido durante el segundo trimestre de este año. En consecuencia, la educación médica del mundo hispanohablante dispone de una nueva plataforma en las que los educadores médicos pueden expresarse y publicar sus investigaciones en este campo. A partir de este momento habrá más oportunidades de publicar trabajos relacionados con la formación de nuestros médicos y de otros profesionales de las ciencias de la salud, habrá mayor difusión del conocimiento que nos es propio, y existirá mayor competencia y colaboración. Indudablemente, para la FEM, la presencia en nuestro medio de Educación Médica representa un estímulo para la mejora y la exigencia de un esfuerzo
Since it was founded almost 20 years ago, the FEM, a non-profit organisation, has been totally convinced of the need to make this new area of knowledge, medical education, more widely known and increase its prestige. Hence, the foundation has worked boldly to keep a publication with the highest scientific quality alive and active. Behind this generous effort made by the FEM there are undoubtedly a series of names and surnames, but it is also only fair to acknowledge, as indispensable parties to this achievement, the backing and patronage of several national and international institutions involved in medical education, such as the Association for Medical Education in Europe (AMEE), the World Federation for Medical Education (WFME), the PanAmerican Federation of Associations of Medical Schools (FEPAFEM-PAFAMS), the Spanish National Conference of Deans of Faculties of Medicine (CNDMED) and the Spanish Society for Medical Education (SEDEM), which from the very earliest stages onwards gave their institutional support to the foundation in its undertakings. Equally important has been the support of an unbeatable publishing team that the directors of the journal have been able to rely on at all times, and who deserve public acknowledgement for their labours.

But what we are dealing with here is not this philanthropic work carried out by the FEM for nearly two decades to foster medical education, but the recovery of the journal Educación Médica. Indeed, after three years of absolute neglect, Elsevier has entrusted the direction of the journal to a reliable and experienced team made up of Dr Millán Núñez-Cortés, Dr Gutiérrez Fuentes and Dr Morán Barrios. With the sponsorship of the Fundación Lilly, their mission will be to resuscitate the publication. The extensive track-record of the new directors of the journal in the field of medical education and the determined backing of such prosperous institutions as the Cátedra Educación-Fundación Lilly guarantee the success of this new era of the journal. The first issue of this second stage came out during the second quarter of this year. Consequently, medical education in the Spanish-speaking world now has a new platform where medical educators can express themselves and publish their research in this field. From now on, there will be more opportunities to publish work related to the training of our doctors and other professionals working in the health sciences, the knowledge gained in our field will be made known to a wider public, and there will be more competition and collaboration. For the FEM, the presence of Educación Médica in our milieu undoubtedly stimulates improvement and the need for 
adicional para mantener e incrementar la calidad de nuestra revista.

Competencia y colaboración son las dos caras de una misma moneda. De hecho, ambas se dan juntas dentro de un sistema social que, aunque dividido por conflictos, está unido por lazos vinculantes. La competencia no debería, en todo caso, marchitar la todavía frágil planta de la educación médica en nuestro país. Por otra parte, la cooperación no debe inhibir la creatividad, la iniciativa y la disensión. La actitud inteligente es la de estimular la variedad de orientaciones enriquecedoras y complementarias, defender la verdad y aumentar la eficacia.

Con este editorial, la FEM quiere dar la bienvenida más cordial a la reedición de Educación Médi$c a$, una revista de la que se siente especialmente próxima. ¡Bienvenidos! an additional effort to maintain and increase the quality of our journal.

Competition and collaboration are two sides of the same coin. In fact, both of them occur within a social system that, although divided by conflicts, is united by binding ties. In any case, competition should not wilt the still fragile plant that is medical education in our country. Moreover, cooperation must not inhibit creativity, initiative and differences of opinion. The intelligent attitude is to stimulate variety in the enriching and complementary orientations, defend the truth and increase efficacy.

With this editorial, the FEM wishes to give a heartfelt welcome to the republication of Educación Médica, a journal that it feels especially close to. Welcome! 